\title{
Urbanisation processes in zones threatened by volcanic activity: The case of Latacunga at the foot of Cotopaxi in Ecuador
}

\begin{abstract}
Where abrupt and dangerous natural phenomena unfold in highly populated areas, they destroy buildings and infrastructure and, above all, cause death and injury among local inhabitants. In the case of the active Ecuadorean volcano Cotopaxi, eruptions have already posed considerable threats to nearby towns and cities due to activated mudslides (lahars) that flow rapidly down its slopes. Interviews conducted with inhabitants of vulnerable residential areas of the town of Latacunga have led the authors to conclude that - in danger zones associated with possible mudslides the lack of building land, inappropriate management of the allocation of building plots and still-inadequate early warning and monitoring systems have favoured the chaotic spread of built-up areas and thus pose a threat to the lives of inhabitants should Cotopaxi erupt again.
\end{abstract}

Keywords

Risk society $\cdot$ public participation $\cdot$ lahars $\cdot$ mudslides $\cdot$ Latacunga $\cdot$ Cotopaxi volcano $\cdot$ Ecuador

(c) University of Warsaw - Faculty of Geography and Regional Studies

\author{
Mirosława Czerny $\mathbb{C}^{1}$, \\ Andrzej Czerny $\mathbb{C}^{2}$ \\ ${ }^{1}$ Faculty of Geography and Regional Studies, \\ University of Warsaw, Warsaw, Poland \\ e-mail:mczerny@uw.edu.pl \\ ${ }^{2}$ Institute of Socio-Economic Geography and Spatial \\ Management, Maria Curie Skłodowska University in \\ Lublin, Lublin, Poland \\ e-mail: aczerny1@gmail.com \\ Received: 27 January 2020 \\ Accepted: 17 September 2020
}

\section{Introduction}

Threats to people caused by different natural phenomena have been an inherent feature of the story of settlement on Earth. Human settlements were always vulnerable to destruction by floods, hurricanes, earthquakes, volcanic eruptions, grass and forest fires, and so on. Phenomena perceived to pose a threats to the existence of human beings are termed natural threats, extreme natural phenomena, natural disasters, and so on (Biernacki et al. 2009); and those that lead to the destruction of settlements and pose a threat to life (so-called extreme phenomena) are now analysed, not only with reference to the natural sciences but also from the point of view of the social sciences and economics. It is of course quite possible for natural disasters of these kinds to occur where similar events have taken place before, when observations or at least historical records exist to tell the tale (Biernacki et al. 2009). Thanks to the existence of precedents, the ever greater amount of knowledge that experts possess allows safeguarding measures to be put in place, which allow possible courses and potential consequences, for example, to be taken into account when planning spatial management and physical development.

Socio-economic geography's approach to natural disasters Among the key aspects of studies associated with the occurrence of unfavourable natural phenomena are those connected with the effects of such events, based on their frequency, intensity and type, and their influence on human life and settlements. The complexity of the phenomena involved, combined with their consequences (in situations where causes need to be examined, and solutions found to limit or compensate for impacts), necessitate analyses that are holistic in nature, as well as being multi-disciplinary and multifaceted. And, as both unfavourable natural phenomena and their scope of impact have to be discussed - and be the subject of action on a global scale - the need for an interdisciplinary approach to the formulation of questions and the search for research perspectives is growing (eds Felgentreff \& Glade 2008). In addition, geographical research should link natural and social issues in studies that seek out forms of protection against potentially drastic changes in human living environments.

The aforementioned paper by Felgentreff and Glade, entitled Naturrisiken und Sozialkatastrophen, is by now a classic. In this paper, the authors consider the term 'natural threat' and how it ought to be understood. In what circumstances does nature pose a risk to people? And is it not perhaps true that it is people - with their buildings, roads, dams, and so on, that have not been adequately safeguarded and protected against sudden and drastic natural happenings - who are actually the ones shaping the image of nature posing a threat? The authors in question go on to assert that academic debate on threats sees two main research perspectives pitted against each other, namely the socio-constructivist and the objectivist. While the former emphasises the socio-cultural element, with knowledge of natural phenomena taken as constructed through social interactions, along with knowledge on threats and the means of safeguarding against them, the latter - conversely - holds that reality is depicted by means of our perception of it (eds Felgentreff \& Glade 2008). Neither of these perspectives allows for the full clarification of the complex interactions between the natural and social systems the moment a natural threat arises.

The debate surrounding natural threats in the social sciences (and in socio-economic geography in particular) mainly revolves around matters of nature's 'responsibility' for such natural 
disasters when serious damage and destruction of property and infrastructure ensues, as well as casualties among inhabitants (eds Felgentreff \& Glade 2008, Gunawan Tejakusumana \& Hanggari Sittadewi 2017, Solecki, Leichenko \& Eisenhauer 2017). An approach of this kind is also often taken by politicians when a disaster is accompanied by some kind of social crisis that proves hard to control and resolve straight away. An economic slowdown is thus a frequent accompanying feature - on a local or regional scale at least.

At the same time, however, views and concepts on relations between humankind and the natural environment, and the threats the latter poses, are starting to assume a different perspective, with a different point of view taken (Felgentreff \& Dombrowsky 2008). This connects with a new approach to crisis management being adopted, and above all to overall management on different reference tiers (be these regional, local or urban, for example), as well as to the tasks that public administration faces (or is expected to be able to face). This is all the more the case in regions where the probability of such unfavourable phenomena arising is greater (Weintrit, Osińska-Skotak \& Pilarska 2018).

Thus, for example, the fact that many people come to harm in regions that are seismically active tends to result from their being within buildings at the time, quite possibly because information regarding the threat - as well as assistance during the occurrence - does not make it to them on time. It may also imply inappropriate or inadequate safeguarding of buildings against shock, or buildings constructed with unsuitable materials, and so on (Felgentreff \& Dombrowsky 2008). This to say that, at some level or point, harm done may boil down to poor human decisions, or decisions taken at the wrong time.

Academic circles thus debate the influence of human beings on nature, and the influence the developments they pursue may have that raise threat levels should some natural disaster arise abruptly. Furthermore, there are many cases in which a phenomenon may not in all conscience be termed 'natural' - such as when the true cause of a flood is its earlier (over-) regulation of the course of a river. Indeed, given that there have now been several millennia during which people have used natural resources, and sought to regulate and 'optimise' natural conditions as they lived in and managed their surroundings, the time seems more than ripe for previous forms of activity and intervention/interference in nature to be reflected upon, in line with the essential need for nature to be protected and be used more wisely than hitherto (Peluso \& Watts 2001; O'Keefe et al. 1976)

Ultimately, many scientists who have engaged in a more exhaustive analysis of a large number of cases of sudden natural events of a catastrophic nature (resulting in major losses of assets and life, locally at least) are inclined to cite human error in relation to how resources are managed, unwillingness to fully implement provisions in spatial plans, inappropriate cuts to necessary spending by central governments as nature protection projects are pursued, and a lack of appropriately developed and maintained infrastructure. If all of the measures alluded to were actually implemented, as opposed to being neglected, this should genuinely mitigate the effects of natural disasters, and curtail the seriousness of the harm done and the losses incurred as a result (Peluso \& Watts 2001; Bleikie et al. 1994; Lisowski 1993).

To understand a problem situation in terms of what constitutes a catastrophe and the relationship between human beings and nature, it is necessary to pursue not only a retrospective analysis of natural events but also a diagnosis of the steps taken to try and prevent future disasters.

Thus, in line with the most modern way of looking at situations, natural disasters are not so much addressed as phenomena that are genuinely natural in character but are instead seen in relation to the society or community affected by them. Thus, an event comes to be recognised as a natural disaster based on the kind of damage wrought upon the environment in which it occurs and on the inhabitants of the given region. In many places (including the Ecuadorean town of Latacunga analysed here), it is possible to assume that a volcanic eruption is going to cause far-reaching destruction, even as the precise consequences are regarded as impossible to anticipate. And the same is true for other phenomena like floods, earthquakes, hurricanes, gales, and so on.

It is hard to determine the causal nature of events arising out of the laws of nature, while the consequences of those events depend on how a society or community is able to cope with them (inter alia, in terms of the management of consequences, risk management in relation to natural disasters, and so on), and on both cultural and social conditions and features. Furthermore, many publications take the view that unfavourable consequences of natural disasters on people can be either prevented or at least reduced considerably, especially in terms of the impact of the natural disasters on inhabited areas. This is also seen as true of so-called natural disasters and those brought about by human beings, in relation to both known initial conditions (i.e. possible scale and scope) and the state of knowledge regarding technical solutions in crises situations. A sharp line may not always be drawn between a natural risk and a natural danger or threat, and studies depend more on description than on quantitative methods (eds Felgentreff \& Glade 2008).

Abrupt, mass-scale events characterised by aboveaverage intensity and losses are widely known as catastrophes or disasters. Equally, reference to 'natural' disasters is taken to denote some explanatory model, given that deployment of the adjective indicates the 'perpetrator', or at least the cause of the phenomenon at work. However, this must imply that full sense is only achieved where natural disasters are set against non-natural ones. In English, it was therefore typical to distinguish between what was natural and what was man-made (eds Felgentreff \& Glade 2008).

As they revisit the discussion on opportunities to limit risks arising from natural phenomena, Felgentreff and Dombrowsky (2008) cite data on earthquake victims. They urge us to account for differences in numbers of victims of such events from one region of the world to another. In Bam (Iran), tremors reaching 6.8 on the Richter scale led to the deaths of 30,000 people, while a Hokkaido earthquake a couple of months earlier (on 25/9/2003), with a magnitude of 8 on the Richter scale, injured 388 people, and resulted in the death of just a single person.

Do we need to look solely at the time of day or the density of population for an explanation? Or are cultural differences important, as well as matters of administration/management and preparation? (Felgentreff \& Dombrowsky 2008). The use of the right construction techniques and the introduction and heeding of relevant regulations on how to behave in situations of threat do reduce numbers of victims. Conversely, there are many examples from different parts of the world in which the failure to follow recommendations regarding (non-)settlement in places at risk of destruction gave rise to huge material losses and human casualties. These examples also relate to the slopes of Ecuadorean volcanoes, including Cotopaxi.

\section{Threat research in geography}

In the social sciences, including geography, research on threats cannot be confined merely to the technological dimension or the calculation of the probability of occurrence and the losses likely to be incurred due to the phenomena (Salazar \& D'Ercole 2009). Threat awareness among inhabitants of a given area is seen as depending on who carries out the assessment. For such an assessment is a consequence, a social construct, and a perception found to vary over time and from one group 
or unit to another, as well as being in line with who makes the assessment and who the direct threat relates to (eds Veyret et al. 2004). Perception (or understanding/appreciation) of a threat is in fact a process that conditions decision-making among individuals or groups in a society vis-à-vis key areas of their lives, not least the choice of a place in which to live (Zayed 2006, Badach, Stasiak \& Baranowski 2018).

Among the influences on such decisions are the sense of identity, an affiliation with a given place and the history of the settlement in general. Notwithstanding the threat connected with existing natural conditions, one place may be viewed by inhabitants as in some way more 'friendly' than another. This has to do with an environment that is known and can be or has been adjusted to, and the perception operates through the prism of the vision of the world around us as influenced by culture in general, and the structure of a society in particular (Douglas 1970; Douglas \& Wildavsky 1982).

The above-mentioned authors maintain that our perceptions differ in line with the defined social group we belong to, with different threats in fact organised into a hierarchy in line with values (and value systems) adhered to and seen to be characterised by different social forms (eds Veyret et al. 2004). And, as each form into which society can organise has its own values, it will also have its own way of ranking threats and its own 'threat portfolio' (Peretti-Watel 2003).

To conceptualise things in the most general way, we can see the determining of the factors influencing threat perception as a task complicated by differentiation in society, which is influenced by such factors as level of education, affiliation with a defined social group, level of income, professional activity, family/cultural/ ethnic aspects, previous experience with disasters, and so on (Alexander 2000). Means of communication also plays a key role, not only in modifying the way a risk or threat is presented, but also in encouraging social shaping, and hence the way a mental picture of a phenomenon is presented (Dauphine 2001, Angiel \& Pokojski 2019). In this context, the analysis of threat perception provided an understanding of the way in which humankind (via individuals or groups) sees the world, its surroundings, inhabited space, and problems connected with a given location.

Comprehensive research on Cotopaxi's perceived danger was conducted by, inter alia, French geographers back in the 1980s and 1990s (D'Ercole \& Metzger 2002). The subject was revisited by Salazar and D'Ercole (2009). An extensive study of threats posed to Quito and more distant areas by Cotopaxi focuses on three spheres of risk perception among inhabitants. The way people perceived the threat of vulcanism and the types of phenomena considered threatening to people who inhabit a given region were studied; then a cartographic analysis of areas facing risks was carried out. The third aspect related to the perception of the risk as such.

The present article in turn considers the three most important issues associated with risk and its perception in a town located at the foot of Cotopaxi. The first of these is the threat of eruption and its consequences. Cartographic analysis (especially of relief) then allows the potential range of the impact of lahars on Latacunga to be presented. After that, open interviews with inhabitants and with the service that monitors volcanic activity allows local people's attitudes to the threat to be recorded, as well as their place of residence.

Latacunga at the foot of Cotopaxi - a settlement within reach of lahars

Regions in developing countries that are densely populated, and subject to the high probability that extreme natural phenomena capable of causing major losses to life and property will arise, are also particularly vulnerable to the negative consequences of such events. As Aguilera Ortíz and Toulkeridis (2005) suggest, it is possible to distinguish three main features characterising each given area which are sufficient to ensure that, should an abrupt natural phenomenon arise, the numbers of victims and level of destruction will be greater than in economically well-developed countries. The above authors mention:

1. prevailing social features of the inhabitants of developing countries, namely poverty, income disparities, limited awareness of threats and the need for preparation to ensure appropriate reactions and conduct in threatening circumstances;

2. the degradation of the natural environment (in particular over-exploitation of existing resources in limited areas);

3. demographic growth, especially in the world's poorest countries (Aguilera Ortíz \& Toulkeridis 2005).

These authors include Ecuador among countries characterised by the above three features. According to UN data, $35 \%$ of Ecuador's population live on less than $\$ 1$ a day, while illiteracy is at $8.4 \%$. At the same time, income disparities in Ecuadorean society are quite glaring, with $52.6 \%$ of the income in the hands of the richest $20 \%$ of society, while the poorest $20 \%$ have just $5.4 \%$ at their disposal (UNICEF 2015).

Ecuador's population is now concentrated in urban areas, which in this case means the presence of people in places threatened by volcanic eruptions, earthquakes, tsunamis, floods, landslides, etc.). Indeed, most of Ecuador's towns and cities are in regions potentially at risk of more than one of these threats. In addition, there has been intensive migration from rural to urban areas that has continued to gather pace since the start of the new millennium, ensuring a rapid increase in demand for land in cities, and leaving the poor with areas where plots are cheap (even if - or indeed because - they are located where the risk of natural disaster is high, such as on volcanic slopes or floodplains, etc.).

Given their high population densities, towns and cities are highly vulnerable to natural disasters, whose outcomes include not only great suffering in local communities but also destruction of infrastructure and public service networks, disruption of fooddistribution systems, and so on. If the risk of such harm to people and property is ever to be reduced, it is essential that cities be equipped with risk-monitoring systems, and with services prepared and ready to act quickly should a disaster situation actually emerge.

Media coverage from regions afflicted by natural disasters nearly always focuses on ad hoc camps and shelters for victims, or on field hospitals and points where packages of humanitarian aid are handed out. What is thus being shown is the solving of problems as and where they arise, with appropriate logistics and rapid action on the part of rescue services. Equally, what really matters to regions threatened by the sudden occurrence of extreme natural phenomena is education, to acquaint inhabitants with the nature of the risk, the ways in which it might be mitigated and controlled for, the actual way in which to behave as the phenomenon in question is evolving, and the warning mechanisms likely to be employed in advance of the event.

It is not easy to assess the level of danger associated with life at the foot of a volcano. Since risk assessment is always a matter of impact and probability of occurrence, the likelihood of an eruption taking place needs to be evaluated, along with assessments of the likely type and strength. Obviously, it is typical for procedures to look to past occurrences of similar phenomena, for example to consider eruption histories so that future events can be modelled. Ecuador - and its Andean region in particular - has many active or dormant volcanoes, while at the same time supporting a dense (and ever denser) human population. Meanwhile, the whole period between 1918 and 1999 brought 


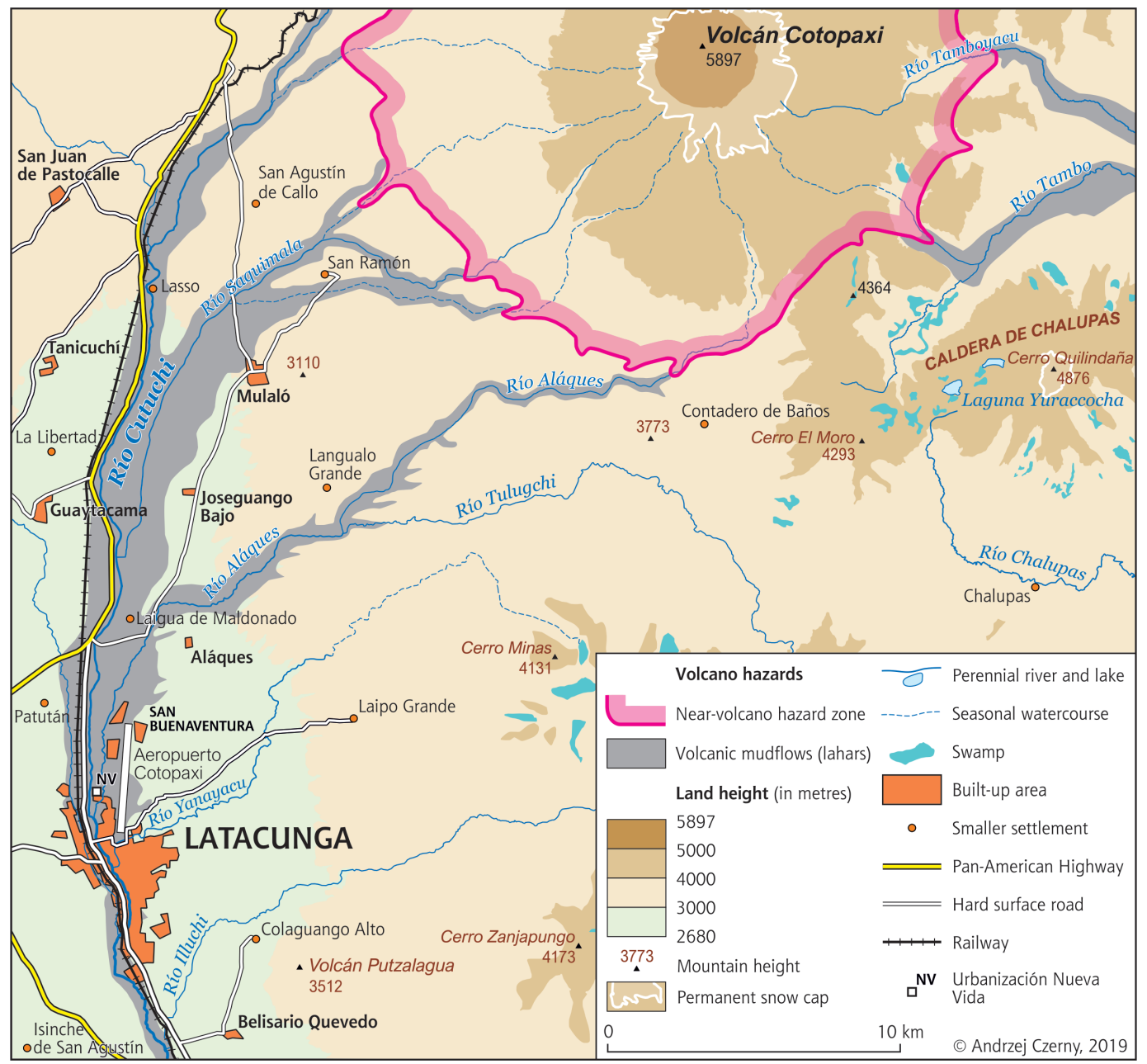

Figure 1. Land threatened by lahars should there be a further eruption of Cotopaxi Source: Own elaboration on the basis of Mapa Regional de Amenazas Volcanicas Potenciales del Volcan Cotopaxi - Zona Sur 2015

no major eruptions, with the result that the volcanic slopes and areas at the foot of cones have ceased to be seen by local people as areas of any elevated habitation risk at all. Furthermore, the eruptions of Guagua Pichincha, Tungurahua and El Reventador that did take place caused no appreciable human losses, encouraging a complacency of limited worth, given the lack of any guarantee that further activity will not be far more intense.

In any case, events of the late 20th and early 21 st centuries would seem to have put paid to the apparently tranquil picture. Eruptions of Guagua Pichincha and Tungurahua (in 1999), El Reventador (in 2002), and La Cumbre in Fernandina (in 2005), as well as Cotopaxi itself in 2015 together ensured not only that inhabitants became acquainted with the existence of threats but also that strategies offering rapid assistance to disaster-hit areas and, above all, that new principles of monitoring, early warning and informing inhabitants of impending danger were devised.

Cotopaxi is a volcano located in the Cordillera Real de los Andes in Ecuador. It is about $60 \mathrm{~km}$ south-east of the national capital, Quito, and around $35 \mathrm{~km}$ from Latacunga, which is south of the volcano (Map 1). Cotopaxi currently peaks at an altitude of 5,897 $\mathrm{m}$ a.s.I. and - as all land above $5,000 \mathrm{~m}$ tends to retain its snow cover year-round, that denotes a frozen area of some $11.6 \mathrm{~km}^{2}$. Furthermore, slopes are covered with thick layers of material accumulated from previous eruptions, be this ash, sand, chunks of rock or rubble. The last eruption took place in 2015 , while 13 such events on a larger scale have taken place since 1532 - when detailed descriptions of Ecuadorean nature by the colonising Spanish were first provided. Most intensive of all, were the eruptions of 1532-4, 1742-4, 1766-8, 1853-4 and 1877 (Mapa Regional de Amenazas Volcanicas 2015). On each of those occasions, the volcano discharged ash, pyroclastic material and abrupt flows of rubble and mud, with the result that considerable losses were incurred among both people and property. At present, Cotopaxi is back in an eruption phase, with ash discharged from the crater on a regular basis over the whole period since 2015.

Cotopaxi is one of the most dangerous volcanoes in Ecuador due to its recent intense activity and its predisposition to cause lahars, due to the melting of the glaciers. Latacunga is located in a small mid-Andean basin through which the Cutuchi River flows. The bottom of the valley is covered with sedimentary rocks formed from volcanic ash. It is about $90 \mathrm{~km}$ away from the capital, Quito. Seismic sensitivity and potential volcanic eruptions from Cotopaxi, as evidenced by the history of the city, are very specific physical and environmental conditions, which significantly affect the development of the city - demographically and spatially (Peltre \& Rodríguez 1987). According to the Mapa Regional de Amenazas Volcanicas Potenciales del Volcan Cotopaxi - Zona Sur 2015, significant built-up areas in the city 
are situated in the volcanic risk zone. Urban development has traditionally developed in a $\mathrm{N}-\mathrm{S}$ direction, on the lowest river terraces. On the slopes of the volcano there are cultivated fields. However, recent years have brought changes to this development pattern. More and more people are building their houses on the slopes of the volcano. Computer simulations have shown that lahars coming down from Cotopaxi will destroy buildings in the river valley (as happened in 2015 and earlier eruptions), but also on the slopes, and from there, if lahars occur, the city's main street and the buildings on both sides of the river will be flooded. The expansion of urban development, although taking place on the slopes, also has poor settlement in a $\mathrm{N}-\mathrm{S}$ direction. Mud streams will flow in a NE-SW direction and will seriously threaten this new development.

Geophysical research, drawing on what is known of the historical eruptions of Cotopaxi, shows that the most major threats to surrounding areas, should the volcano erupt again, will be those posed by mudslides or lahars. This is the lesson learned from the history of volcanic eruptions in the Andean states, in terms of damage done and numbers of fatalities caused. A prime example would be that of the Nevado del Ruiz volcano in Colombia, whose 1985 eruption generated a mudslide that killed over 22,000 people in the town of Armero (Aguilera Ortíz \& Toulkeridis 2005).

Based on the analysis of the course of the Cotopaxi eruption in 2015 , it can be said that:

- The dangers associated with an eruption of Cotopaxi are basically the following: ash fall, pyroclastic flows and lahars.

- To date, ash fall is a danger that has been underestimated, since probable impacts on air traffic have not been taken into account or the eventual need to suspend, for a undetermined period of time, the operation of the airports in Quito, Guayaquil and Manta, in addition to the probably collapse of unstable roofs and the destruction of flower crops.

- Throughout the eruptive history of Cotopaxi, the lahars have been the most destructive and recurrent phenomenon of volcanic activity. All the natural drainage that originates in the volcanic cone, constitute routes that facilitate the transit of lahars and, consequently, the scenario of the lahars reaching the river valleys (El Volcán Cotopaxi ... 2005).

As explained above, the characteristics of Cotopaxi, and the distance that separates the volcano from the main human settlements in the Latacunga and Valle areas of Los Chillos, make the journey time quite short; therefore, it is considered that the best and possibly the only alternative to safeguard the safety of the population, would consist in the installation and proper use of an early warning system (called SAT), independent of the volcanic monitoring system.

In the last 471 years, the volcanic activity of Cotopaxi has generated at least ten (10) events that produced destructive lahars. Therefore, we must recognise that these are not separate events but, on the contrary, the volcanic episodes extend over a period of several years. (El Volcán Cotopaxi ... 2005).

The threat of lahars is aggravated by the geology of the Cutuchi valley where Latacunga is located. Latacunga is situated in the large inter-Andean basin of Latacunga and Ambato. The hydrographic and orographic conditions are more straightforward than in the region north of the basin. However, the fact that there are two main mountain ranges makes the situation quite complicated, especially so in the eastern mountain range. Geologically, it is located on Cangahua. Materials from lahar, colluvial and lacustrine deposits, as well as ashes, volcanicsedimentary tuffs and conglomerate materials are irregularly arranged and covered by powerful pumice layers of different sizes (Plan de Desarrollo y Ordenamiento Territorial 2016-2018).
The volcanic products come from the Pleistocene and are related to glaciations that prevailed in the mountains (Herrera Benalcázar 2013). The fluvio-lacustrine deposits are located mainly on the left side of the Cutuchi River, and are covered by large pumice deposits. Above these, there is a horizon with balls of the Coprinisphaera ecuadoriensis beetle, described by Sauer in 1965 (in Herrera Benalcázar 2013). During the Pliocene, the LatacungaAmbato basin was filled by two main units (Herrera Benalcázar 2013) of the Latacunga Formation: a lower unit composed of lahars and lava, and an upper unit of fluvio-lacustrine deposits. The volcanic activity of this period can be evidenced by the strato-volcanoes present in the Inter-Andean Depression (the layer is $250 \mathrm{~m}$ thick). Most of the urban constructions of Latacunga are located on the material of the Latacunga Formation.

What happens, specifically, is that an eruption impacts rapidly upon the snow and ice, often covering both the summit and slopes of a volcanic cone, with melting ensuing immediately, and with a stream of muddy water generated that can take rock, large amounts of volcanic ash and other rocky material with it. High rates of flow are achieved, with much depending on inclinations of slopes; but it is typical for mudslides to follow rivulets and channels that have already taken shape. Since downpours of rain are encouraged by convection current in the areas around volcanoes, mudslides may also be generated in this way. While lahars may remain short, they may also travel tens of kilometres. Those associated with Nevado del Ruiz travelled $60 \mathrm{~km}$, while the 1877 lahars flowing down from Cotopaxi covered the entire distance (in excess of $300 \mathrm{~km}$ ) to the Pacific Ocean. The huge energy present in the mass of water mixed with rocky material, which has a high density and large overall size, ensures the very destructive nature of a phenomenon entirely capable of demolishing residential districts or even whole towns, with many losing their lives in the process. Lahar flows may be of the order of tens of thousands of cubic metres per second, while mean speed depends on both slope and mass, but is typically $20-40 \mathrm{kmh}$. In 1987, a lahar that arose in the aftermath of a Cotopaxi eruption made it down to the port of Esmeraldas on the Pacific shoreline after some 18 hours (Aguilera Ortíz \& Toulkeridis 2005).

Where volcanoes are dormant, the threat posed to people is greater, and the more developed the economy and settlement on the volcanic slopes become. Lahars flowing down from mountain slopes do indeed follow river valleys, and these are the places where settlement tends to be the most fully developed. Residents of such districts have no awareness of the danger they face, and the fact that the last eruption may have taken place decades ago leaves people unable to imagine the destructive force a lahar is capable of achieving. Since the 1980s, numerical models of those potential threats have come into being (even if threats were previously assessed solely in line with geographical and stratigraphic information) and augmented by empirical methods, with the thickness of layers carried off by previous eruptioninduced lahars being measured.

In the case of Cotopaxi, lahars can travel several tens of kilometres and cover extensive areas on the volcano's slopes and at its foot; for centuries, they have destroyed or much obstructed road infrastructure and housing in regions characterised by high densities of population. The towns of Latacunga and Salcedo are located in the Cutuchi Valley, which is fed by rivers from the slopes of Cotopaxi, making it especially vulnerable to mudslides induced by eruptions. Flows of pyroclastic material, formed mainly from andesite, have not hitherto travelled further than $15 \mathrm{~km}$. In contrast, mudslides and flows of friable rock have passed along the Cutuchi Valley, some as far as $10-20 \mathrm{~km}$ south of Latacunga (Mapa Regional... 2015). Geological and stratigraphic research carried out at the end of the 20th century make it clear 


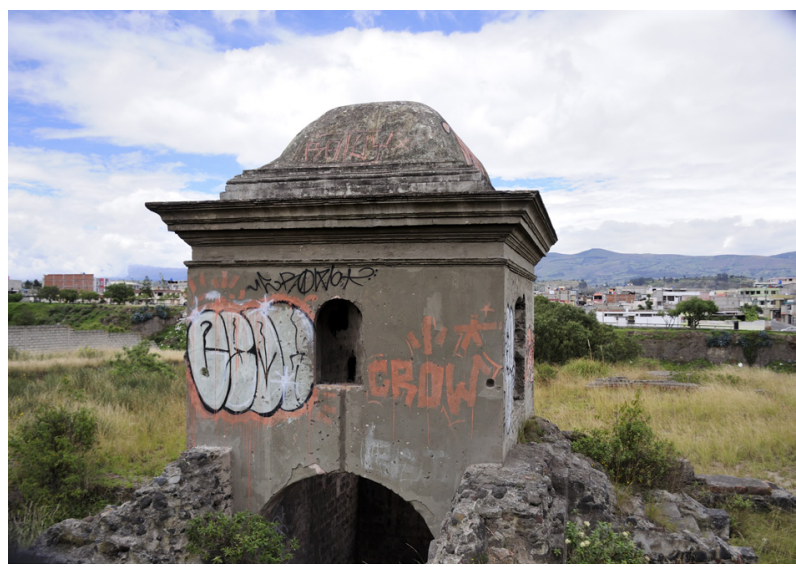

Figure 2. Latacunga - the old San Gabriel textile mill, located in the river valley and so inundated by mudslides following the 1877 eruption of Cotopaxi

Photo taken by: Mirosława Czerny

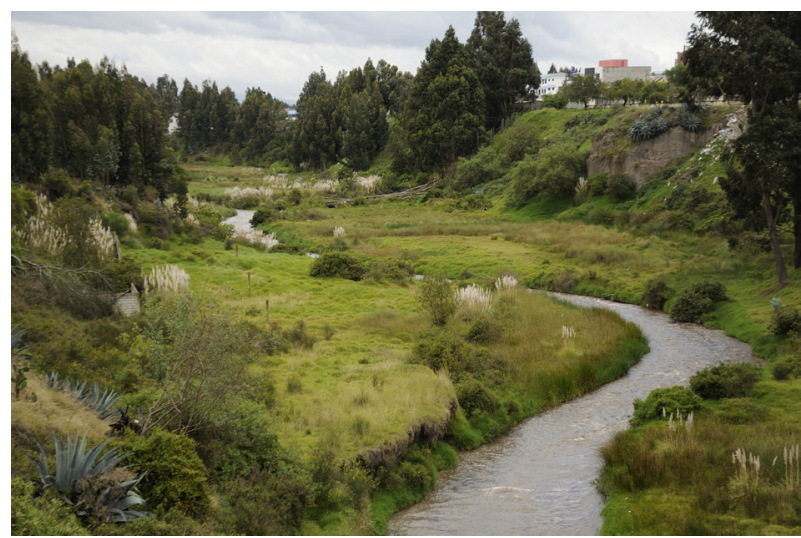

Figure 3. Cutuchi River in Latacunga Photo taken by: Mirosława Czerny

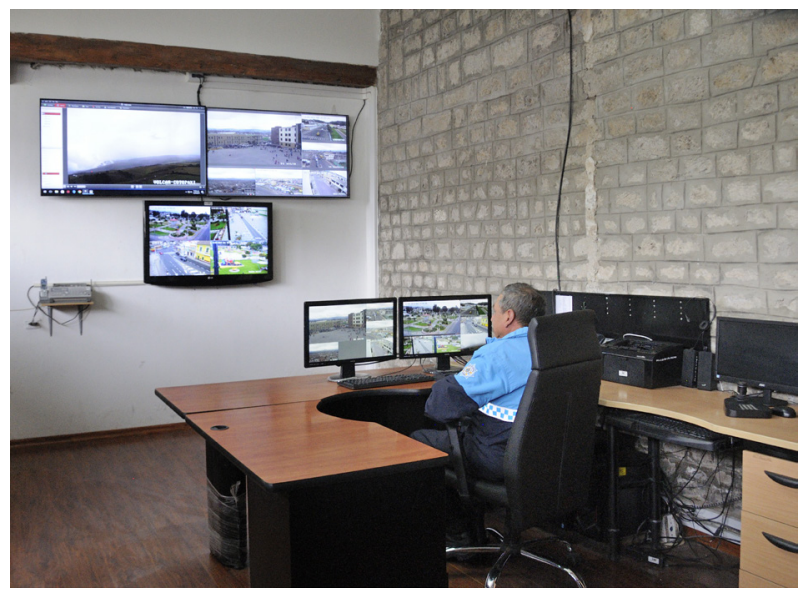

Figure 4. Monitoring room. One camera shows the volcano Cotopaxi all the time Photo taken by: Mirosława Czerny that any upcoming eruption may be powerful enough to threaten settlements along the said valley.

\section{Crisis management as exemplified by Latacunga}

Following Cotopaxi's last eruption in 2015, an alert system called the Sistema de Alerta Temprana (SAT) was developed and implemented throughout the province. 2015 also brought the development and publication by the Instituto Geográfico Militar of a map of eruption threats capable of affecting inhabitants in the Cotopaxi area (Mapa Regional de Amenazas Volcanicas Potenciales del Volcan Cotopaxi - Zona Sur 2015). This is in fact an updated version of a 2004 map, now developed on a scale of 1:50 000, mainly by scientists at the Geophysical Institute of the Escuela Politecnica Nacional. As the publisher suggested, this is an instrument to be used in regional planning, and should be taken into account by bodies of the local administration, along with organisations responsible for first aid in the event of Cotopaxi's erupting once again. The zone of potential threat due to mudslides was determined by reference to their extent at the time of the last powerful eruption of the volcano, dated 26 June 1877.

The SAT system is in turn operated by the Dirección de Seguridad Ciudadana y Gestión de Riesgos, given its responsibility for safety and risk management in the urban area. SAT is a tool that allows for the rapid supply of information provided continually by seismological observatories and government agencies, as well as a general monitoring system. Obviously, the main point of interest is the detection of the threat of an eruption, and the rapid dissemination of information to places endangered, in order for evacuation of the populace to be organised. All of this is done to avoid or reduce threat levels and prepare people to react rapidly to information as it comes in. In the case of Latacunga, the greatest threat is indeed posed by mudslides or lahars, which would flow down from the summit of the volcanic cone where snow cover lies throughout the year.

The system sounding the alarm in respect of an upcoming threat comprises:

- the monitoring and protection system (with cameras and information boards);

- communications systems (by radio, and so on);

- $\quad$ the alarm system proper, with loudspeakers attached.

The monitoring system encompasses seven sites in the town, and there are also loudspeakers and alarms at seven points.

A separate component related to risk management concerns Acts on Land Use, and in particular on construction in areas threatened by the occurrence of mudslides. Article 55 of the key Act is concerned with the designation of land for the construction of permanent residential buildings, and land use exclusively or jointly for housing construction, as well as land for individual or collective housing. Regulations assume the division of the town as a whole into land designated for building on a conditional basis (with economic activity and the further development of infrastructure permitted to a limited extent). The study on eruption threats posed by Cotopaxi, as produced by the Escuela Politecnica Nacional, draws a distinction between zones characterised by:

- a low level of threat, within which consent is given for the construction of individual homes, in line with relevant guidelines on numbers of floors (a maximum of two is allowed), evacuation routes and the need to safeguard buildings;

- a moderate level of threat, within which permission is given for the building of single-family, single-storey homes - in line with the division of land into building plots (the building 
permit also has a map of the route potentially taken by posteruption mudflows appended to it);

- a high level of threat, within which new developments of all kinds are forbidden (though the land is in part used agriculturally).

The latest satellite images show just how many buildings have appeared in both of the zones facing a potential threat. This is particularly true of services, which are often provided in buildings that also serve residential functions. Residents who need dwellings or available building plots away from the river valley build homes on the volcanic slopes and thus accept the risk of living in the danger zone. The authorities' activities in monitoring the volcano and issuing warnings will not be effective in preventing destruction and loss of life if people continue to settle on the slopes. Yet a new land-use plan was still being devised as of mid-2019; an even more urgent question concerns the need to have plans for the evacuation of the populace drawn up and ready. Firms in the area of threat have had evacuation plans ready since February 2019.

Evaluation of the level of vulnerability (risk perception) to volcanic danger by the inhabitants of the Barrios of Ciudadela Nueva Vida and Campo Verde

Evaluation of the level of vulnerability is directly or indirectly linked to the places perceived as potentially affected by destructive phenomena. The views of the threatened population do not generally coincide with the opinions of specialists, which makes it difficult to manage risk in a given area. To demonstrate this phenomenon, we have chosen to intervene in relation to the inhabitants of new neighbourhoods built in the area who are most exposed to lahar risks. People who belong to different groups of inhabitants may have very different ideas of the same external reality. Lynch (1960) had already shown in 1960 that the image the inhabitants of Boston had of their city, of its structuring elements, was very different to the vision of specialists (such as town planners). Lynch shows in his study that the knowledge of this perception [...] allows the town planner, the architect or the sociologist to substantially improve the planning, the urban composition and the quality of life of the inhabitants

In April 2019, field observations were made - and extended interviews carried out - in the matter of the threat or risk faced in Latacunga, specifically in the two Barrios of Ciudadela Nueva Vida and Campo Verde. In these places, the system used to keep inhabitants informed of threats, and the management system, have been developed in line with experience and analysis of the range of occurrence of lahars, and the reactions of inhabitants back in 2015, when an eruption of Cotopaxi brought mudslides into settlements on the volcano's southern and eastern slopes, destroying buildings and leading to a large number of fatalities.

In the work presented here, we did not carry out mind maps as Lynch did, but concentrated on analysing the ideas that people have about where they live and the meaning of the threat they face. We had the opportunity to participate in a workshop for the residents of the barrios. The selection of the sample was accidental and voluntary and included both women and men. The meeting was attended by those who, having no other possibility of getting a home, decided to build a house in the area themselves. During the workshop we presented the maps of the site, along with the outline of the path of potential lahars with basic spatial references: rivers, main roads, urban layout and the names of the main places of interest. Once the neighbourhood was located on the map, the workshop participants (40 people) were asked to define those places that, according to them, would be most affected by volcanic products in the event of a Cotopaxi eruption.
This allowed for discussion about the spaces considered the most exposed for the people interviewed.

Only recently have residents in the relevant areas become acquainted with maps presenting the level of threat. Since 2018, SAT analyses have provided grounds for authorities to refuse to consent to housebuilding in zones facing a very high risk of mudslide inundation. And, since 2015 , as long as threat maps did not exist or had not been approved by the local authorities, new building permits were not issued at all. Today, permits for new developments are issued in relation to zones of low- or moderatelevel threats, for both firms and single-family housing, where plot areas are of at least $1,500 \mathrm{~m}^{2}$. Permission for the construction of multi-family housing is also granted in the low-threat zones.

The 2015 eruption of the volcano that caused so much destruction in the city did not bring about any increase in levels of internal migration in Latacunga, whereby inhabitants might have left danger zones and transferred to other, safer places. The area most at risk is in fact the valley of the Cutuchi, which flows through the centre of the town. The main commercial street runs along the riverbank, and key institutions and services are also located along it. A valley location is attractive to businesses, and this ensures that the valley area is not abandoned by either residents or service-providers, notwithstanding the threat the volcano poses.

The first settlers appeared in Ciudadela Nueva Vida and Campo Verde in 1963-4, but it was not until two decades later that the residential districts that had come into existence were transformed from private to public. In 2000 , they were brought within the system of public services and urban infrastructure, and between that time and 2008 there was a further major influx of inhabitants, and further development of the residential built-up area. However, no physical development plan for these areas existed, and - paradoxically or not - it was often members of the military and their families who moved on to land much threatened by lahars and not in fact meriting any development of settlement whatsoever. What is more, the relevant services did not prepare strategies according to which the areas in question would be evacuated in the event of a volcanic eruption. A lack of plans continues to define the situation as of mid-2019, despite the fact that (in the view of the services that monitor volcanic activity) residents of the eastern and western parts of the settled area would have 25 and 30 minutes, respectively, to leave their homes.

Information from 15 August 2015 (the last time Cotopaxi had a fairly major eruption) reveals that, following the onset of that event, the settlement of Nueva Vida had one hour and twelve minutes to evacuate in a northerly direction, and one hour and eighteen minutes to escape to the south. Literally every minute counted in both cases, as the roads taken ended up being crossed by a wave of mud between 1.1 and $2.5 \mathrm{~m}$ high.

In the Nueva Vida/Campo Verde area, there are 420 plots that have been built on, or some 500 homes, and hence 2,200 inhabitants approximately. The study on the threats facing this area was only completed in 2018. There is still no designation of which roads are to be used in the event of an eruption-induced need to evacuate these areas abruptly. Also lacking is a plan or map of such an evacuation. Public consultations on how risks might be reduced were attempted, but ultimately abandoned after these proved to be occasions for constant quarrelling.

In the case of the neighbouring residential area now known as Colectivo Zona Muerta - given its having been entirely devastated by the eruption that took place on 15 August 2015 - it has been excluded from all construction plans until 2035. At the same time, there are many there who have been left without a roof over their heads and do not really have anywhere to go. They would prefer to return to their old places and be able to rebuild 


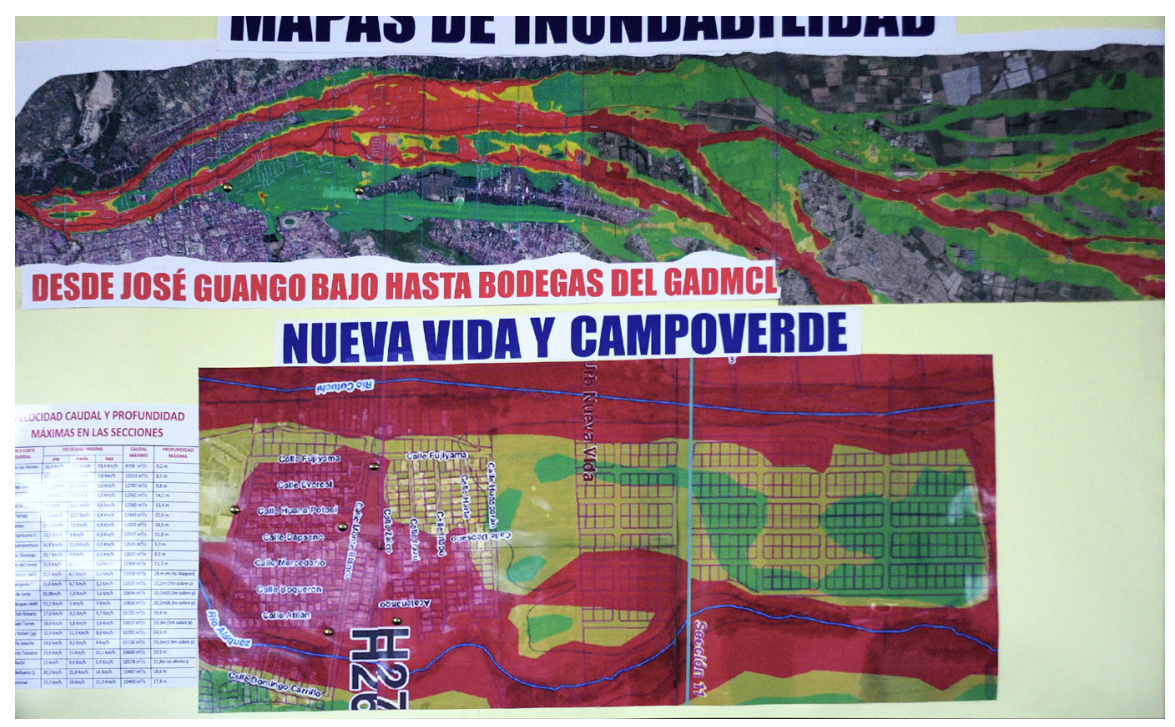

Figure 5. Nueva Vida/Campo Verde - places threatened by flooding of lahars

Source: presentation for members of the Geographical Congress made by Servicio Nacional de Gestión de Riesgos y Emergencia, 14 April 2019

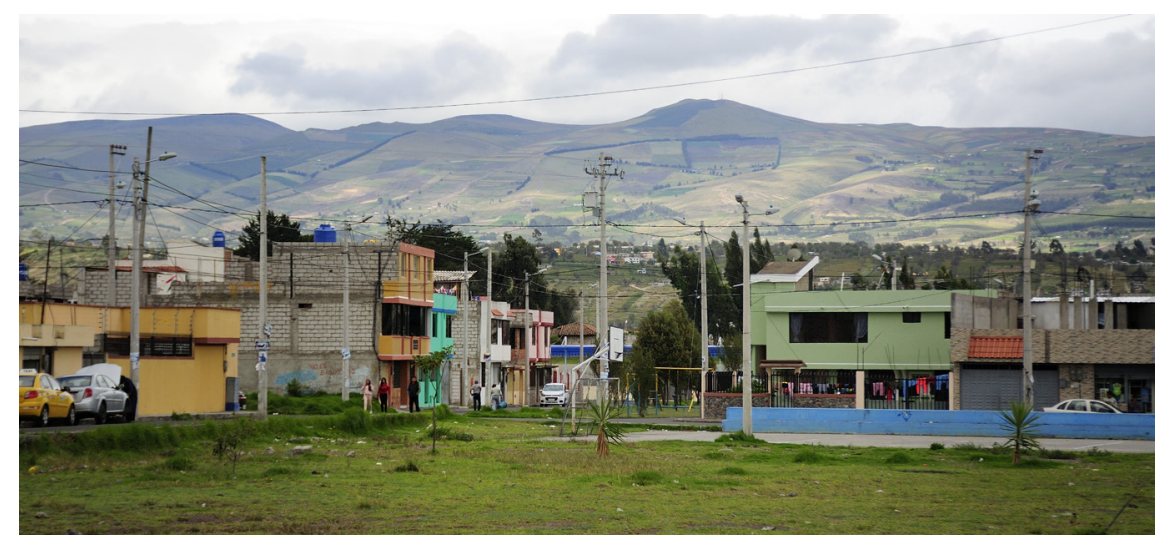

Figures 6. New housing construction in Nueva Vida/Campo Verde (Latacunga) Photo taken by: Mirosława Czerny

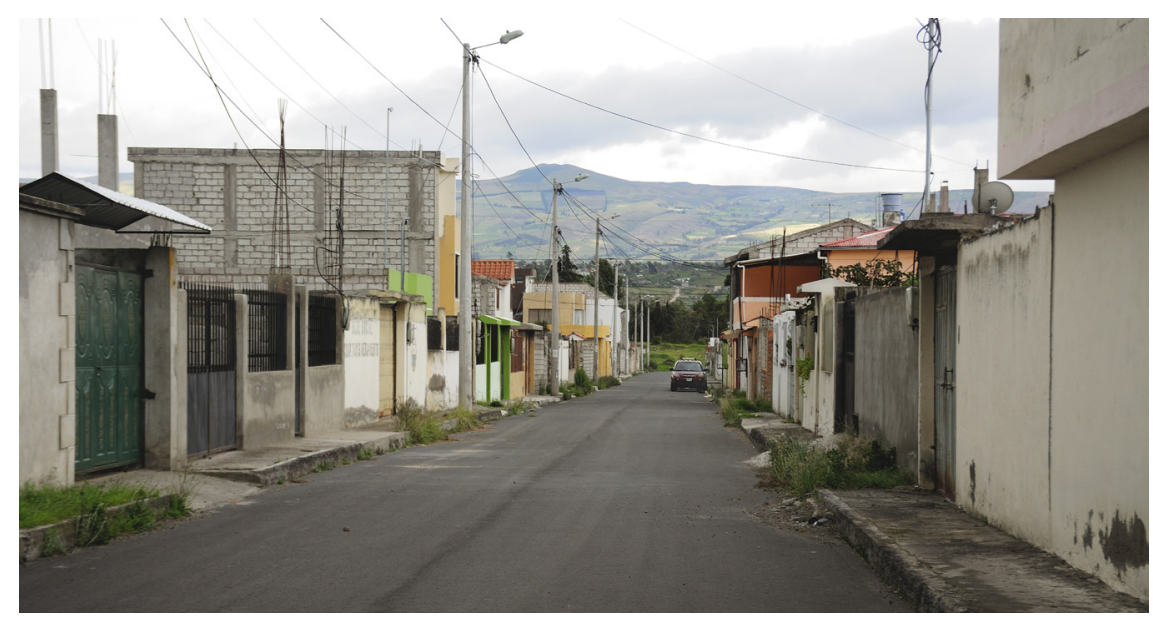

Figures 7. New housing construction in Nueva Vida/Campo Verde (Latacunga) Photo taken by: Mirosława Czerny 


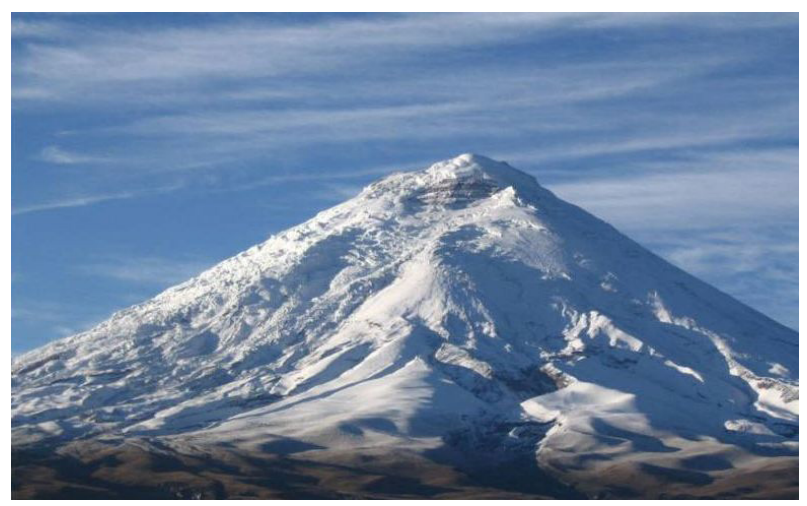

Figure 8. Cotopaxi volcano

Photo taken by: Jerzy Makowski

there. But for safety reasons the authorities will not (now) consent to that. Determined inhabitants, failing to receive permission to return to their old homes, lodged a complaint against the Government of Ecuador with the tribunal of the Organization of American States. Such activity makes it clear that these people feel they have been wronged, and do not therefore acknowledge the argument that they are at risk of death or else of the loss of their homes yet again. The authorities' reaction - to the effect that 'no building is allowed' - does not suit them, but what are they to do?

The problem is all the more serious given that the residential areas involved are the ones that will be inundated first by mudslides, should Cotopaxi erupt. In 2015, after the last eruption, local people were not invited by the authorities to the monitoring centre to discuss the issue of the threat posed.

\section{Conclusion}

Research into threat perception represents a key matter for those interested in human relations with the geographical environment. The studies carried out in this regard make it clear that people's perceptions of the danger arising from abrupt and unpredicted (or indeed unpredictable) natural phenomena tend to differ from one region to another; they differ too according to conditions in the geographical environment, the settlement history, culture and traditions.

The interviews we conducted allowed us to conclude that, while inhabitants have a high level of awareness of the threats that exist, this does not translate into a very clear sense of being endangered. Thus, inhabitants have built homes along the routes that mudflows may take; should such lahars occur sooner or later through an eruption of Cotopaxi, what they have built may be destroyed. In spite of that fact, people do not tend to see this threat as one that could arise abruptly anytime soon.

First, the population is aware that a Cotopaxi eruption will occur in the next few years, although they have less clear ideas as to when the next eruption will occur. The community leaders present at the meeting expressed the clearest awareness of the phenomenon. About $10 \%$ of those present expressed the belief that it could happen at any time. Regarding the threat posed by lahars, all expressed the opinion that these had been the most harmful element for the city in 2015 . However, they have built their houses on land directly located on the potential route of the lahars.

Second, as mentioned above, the inhabitants have only recently become familiar with the maps of the risk areas. From these maps, it can be noted that from south to north, the areas the population considers most exposed are approximately where the Pita and Santa Clara rivers are located. According to the scientists, the sectors exposed to the lahars start at the level of the crater of the volcano located in the north, more than $40 \mathrm{~km}$ from the valley and continue towards the north (see map). In their study, Salazar and D'Ercole also mention that an important part of the population can be considered to have limited knowledge of the lahar phenomenon, just as it turned out in this study. On the other hand, some people consider that products other than lahars, such as ashes, volcanic bombs or volcanic lava, could be important sources of danger, despite the distance.

Finally, it appears that the Geophysical Institute's volcanic hazard maps, sometimes published by the press or presented at workshops, seminars or awareness campaigns by local authorities, have influenced certain people: particularly the 1988 map, which showed larger exposed areas than the updated 2004 map (Salazar \& D'Ercole 2009). This thesis was confirmed during the research conducted by the authors in 2019.

During the meeting, the inhabitants of the area studied seemed very worried and even scared. It seemed that the seriousness of the problem had not been discussed with them before. However, in the discussion they concentrated on the issue of omissions of local authorities and the lack of protection. They do not perceive the potential scale of the damage. According to them the damage would be minor, limited to material losses and various disturbances in territorial functioning. When they saw the risk maps, they said that no one had shown them to them before. However, upon listening to the explanations of why they are settling in the area, one can conclude that they feel threatened to varying degrees - very strongly in some cases and especially in the San Rafael area.

Risk perception considers the effects of volcanic eruptions in terms of consequences for people and property. During the workshop organised on the site, two important issues were discussed: on the one hand, the point of view of the respondents on the potential damage and social vulnerability in the area where they live; on the other hand, the perception of personal risk - in other words, the respondents' perception of risk to them in their place of residence.

Effective crisis management implies the most correct adaptation of the views of the different actors involved. The research highlights the diversity (and even divergence) of views between scientists and the population, and even within the population itself, in terms of hazard or risk perception. The information offered by this type of research unquestionably presents a conflict of interest between people occupying a given area (because they have no other choice) and the purpose of prevention services - to protect the lives of people settled where there is a high risk of damage. The following are of interest to risk and crisis managers, but it is worth considering the real usefulness of the question in terms of preventive action and reduction of the population's vulnerability. Two limitations are often mentioned - the lack of administrative tools to prevent the development of settlements in inappropriate places and poor risk education, both for children and adults.

In this kind of case it is possible to refer to a non-symmetrical human-environment relationship, in the sense that people are aware of the danger but take no action to safeguard themselves against it. While it is true that people meeting with local authorities do demand access to safe building plots, they also - at the same time - seek approval for potentially at-risk work they have already carried out.

\section{ORCID}

Mirosława Czerny (1) https://orcid.org/0000-0002-8216-9912 Andrzej Czerny (I) https://orcid.org/0000-0001-7006-1990 


\section{References}

Aguilera Ortíz, E \& Toulkeridis, T 2005, El Volcán Cotopaxi, una amenaza que acecha. Proyecto de prevención de los riesgos asociados con la erupción del volcán Cotopaxi - Prevolco - Ecuador 2004 - 2005 [The Cotopaxi Volcano, a looming threat. Project for the prevention of risks associated with the eruption of the Cotopaxi volcano - Prevolco - Ecuador 2004 - 2005], Fundación FOES, Quito.

Alexander, D, 2000, Confronting, catastrophe, Terra Publishing, Hertfordshire.

Angiel, J, Pokojski, W 2019, Education for sustainable development - from students' and geography teachers' knowledge to educational activities. Miscellanea Geographica, Volume 23, Issue 1, pp. 161-175.

Badach, J M, Stasia A \& Baranowski, A, 2018. The role of urban movements in the process of local spatial planning and the development of participation mechanism, Miscellanea Geographica Volume 22, Issue 4, pp. 187-196

Biernacki, W, Bokwa, A, Działek, J \& Padło, T 2009, Społeczności lokalne wobec zagrożeń przyrodniczych i klęsk żywiołowych [Local communities facing natural hazards and disasters], IGiGP, Kraków.

Bleikie, P, Cannon, T, Davis, I \& Wisner, B 1994, At risk. Natural hazards, people's vulnerability, and disasters, Routledge, New York.

Dauphine, A 2001, Risques et catastrophes. Observer, spatialiser, comprendre, gérer [Risks and disasters. Observing, spatializing, understanding, managing], Armand Colin, Paris.

D'Ercole, R \& Metzger, P 2002, 'Diferenciaciones espaciales y sociales, representaciones y manejo del riesgo volcanico en Quito' ['Spatial and social differentiations, representations and management of volcanic risk in Quito'], Memorias del Seminario, Gestión de riesgos y prevención de desastres, Quito, 24-25 de enero de 2001, Flacso, Coopi, ECHO, pp. 40-54

Douglas, M 1970, Natural symbols: explorations in cosmology, Pantheon Books, New York.

Douglas, M \& Wildavsky, AB 1982, Risk and culture: An essay on the selection of technical and environmental dangers, Berkeley, University of California Press.

El Volcán Cotopaxi, una amenaza que cosecha 2005, Proyecto de prevención de los riesgos asociados con la erupción del Volcán Cotopaxi - Prevolco - Ecuador 2004-2005 [The Cotopaxi Volcano, a threat that reaps 2005, Project for the prevention of risks associated with the eruption of the Cotopaxi Volcano - Prevolco - Ecuador 2004-2005], Coordinación General y Administración: Fundación para el Desarrollo Socioambiental FOES.

Felgentreff, C \& Dombrowsky, WR 2008, 'Hazard, Risiko und Katastrophenforschung' ['Hazard, risk and disaster research'] in Naturrisiken und Sozialkatastrophen [Natural risks and social disasters], eds C Felgentreff \& T Glade, Spektrum Akademische Varlag, Berlin, Heidelberg, pp. 13-29.

Felgentreff, C \& Glade, T (eds) 2008, Naturrisiken und Sozialkatastrophen [Natural risks and social disasters], Spektrum Akademische Varlag, Berlin, Heidelberg.

Gunawan Tejakusuma, I, Hanggari Sittadewi, E. 2017, Qualitative study of disaster preparedness in an Indonesian village: Interviews with survivors of flash flooding near Bandung, Miscellanea Geographica, Volume 21, Issue 4, pp. 179-183.
Herrera Benalcázar, FD 2013, Caracterización de los depósitos de avalanchas de escombros en el tramo Pillaro-Patate [Characterisation of the debris avalanche deposits in the Pillaro-Patate section], Universidad Central del Ecuador, Quito, Ecuador.

Lynch, K 1960, The image of the city, Cambridge, Massachusetts, The Mit Press.

Lisowski, A 1993, Skutki występowania wybranych zagrożeń naturalnych $i$ ich percepcja $w$ Polsce [The effects of selected natural hazards and their perception in Poland], Wydział Geografii i Studiów Regionalnych Uniwersytetu Warszawskiego, Warszawa.

Mapa regional de amenazas volcánicas potenciales del Volcan Cotopaxi - zona sur [Regional map of potential volcanic hazards of the Cotopaxi Volcano - southern zone] 2015, Instituto Geográfico Militar, Quito.

O'Keefe, P, Westgat, K \& Wisner, B 1976, 'Taking the naturalness out of natural disasters', Nature, vol. 260, pp. 566-567.

Peltre, P \& Rodríguez, J 1987, 'Problemas ambientales crecimiento urbano. Casos de Manta y Latacunga' ['Environmental problems of urban growth. Cases of Manta and Latacunga'] in El espacio urbano en el Ecuador, ed. Urbana, Región y Crecimiento, Centro Ecuatoriano de Investigación Geográfica, Quito, Ecuador, pp. 184-191.

Peluso, NL \& Watts, M 2001, 'Violent Environments' in Violent Environments, eds NL Peluso \& M Watts, Cornell University Press, Ithaca, pp. 3-38.

Peretti-Watel, P 2003, Sociologie du risqué [Sociology of risk], Paris, Armand Colin, Collection U.

Plan de Desarrollo y Ordenamiento Territorial 2016-2028 [Plan of Development and Territorial Management, 2016-2028]. 2016, Latacunga, Gobierno Autónomo, Latacunga.

Salazar, D \& D'Ercole, R 2009, 'Percepción del riesgo asociado al Volcán Cotopaxi y vulnerabilidad en el Valle de Los Chillos (Ecuador)' ['Risk perception associated with the Cotopaxi Volcano and vulnerability in the Los Chillos Valley (Ecuador)'], Bulletin de l'Insitut français d'études andines, vol. 38(3), pp. 849-871.

Solecki, W, Leichenko, R \& Eisenhauer, D, 2017, Extreme Climate Events, Household Decision-Making and Transitions in the Immediate Aftermath of Hurricane Sandy, Miscellanea Geographica, Volume 21, Issue 4, pp. 139-150

Veyret, Y, Beucher, S \& Reghezza, M (eds) 2004, Les risques [The Risks], Rosny-sous-Bois, Breal. Coll. Amphi Geographie.

Weintrit, B, Osińska-Skotak, K \& Pilarska, M, 2018, Feasibility study of flood risk monitoring based on optical satellite data. Miscellanea Geographica, Volume 22, Issue 3, pp. 172-180.

Zayed, J 2006, 'Analyse des risques sur la sante humaine: perception des risques, principe de precaution', Ponencia presentada en el coloquio international Developpement, environnement et sante ['Analysis of risks to human health: risk perception, principleas a precaution', Paper presented at the international colloquium Development, environment and health], Bamako, Mali (12-16 June 2006). 